\title{
BUSINESS MODEL DEVELOPMENT STRATEGY FOR FROZEN FOOD MICRO- BUSINESSES IN THE NEW NORMAL ERA (CASE STUDY: CV XYZ)
}

\author{
Ardelia Nadhilah Rosyad ${ }^{* 1}$, Rizal Syarief ${ }^{*}$, M. Faiz Syuaib ${ }^{* *}$ \\ ${ }^{*}$ School of Business, IPB University \\ Jl. Raya Pajajaran, Bogor 16151, Indonesia \\ ${ }^{* *}$ Department of Mechanical and Biosystem Engineering, Faculty of Agricultural Technology, IPB University \\ Jl. Lingkar Akademik, IPB Darmaga Campus, Bogor 16002, Indonesia
}

\begin{abstract}
The limitation of community movement in the new normal era has changed consumer behaviour to frozen food products, and digital marketing has been used to carry out a transaction. CV XYZ, a company that produces frozen food, must optimize the existing opportunities and utilize its strengths. The high level of social hygiene and the increasing demand for food integrity has become a challenge the company is facing today. Other than that, the company is now facing several obstacles on product development and channel limitation. Therefore, this research is aimed to identify the business model available, develop an alternative business strategy and create a new business model innovation. The data sources are from primary and secondary data; the primary data are observation, interview, FGD with the research experts, businessmen, and consumer survey. The secondary data used are literature studies such as journals, thesis, dissertation, economic data, and textbooks. Data processing techniques are carried out by analyzing business model canvas, SWOT, internal factor evaluation, and external factor evaluation, grand strategy, and $360^{\circ}$ business model innovation. The result of SWOT analysis maps the company in quadrant one, which indicates the company is in high market growth and strong competitive position, so the company needs to improve its business model through BMI $360^{\circ}$ analysis model. This model is used to help see the business activity process from creating value in the upstream until it can become the core competition downstream of a business process.
\end{abstract}

Keywords: $360^{\circ}$ business model innovation, business model canvas, small and medium enterprise (SMEs), SWOT, value

\begin{abstract}
Abstrak: Keterbatasan gerak masyarakat di era new normal telah mengubah perilaku konsumsi yang beralih ke produk pangan beku dan menggunakan pemasaran digital untuk melakukan transaksi. CV XYZ sebagai perusahaan yang memproduksi frozen food harus mampu mengoptimalkan peluang yang ada dan memanfaatkan kekuatan yang dimiliki. Tingginya tingkat higine masyarakat dan permintaan kebutuhan pangan yang semakin meningkat menjadi tantangan yang dihadapi perusahaan saat ini. Selain itu, perusahaan kini menghadapi beberapa kendala dalam hal pengembangan produk dan keterbatasan saluran. Oleh karena itu, penelitian ini bertujuan untuk mengidentifikasi model bisnis yang ada, mengembangkan strategi alternatif bisnis dan menciptakan inovasi model bisnis yang baru. Sumber data berasal dari data primer dan data sekunder; data primer berupa observasi, wawancara, FGD dengan pakar, pelaku usaha dan survei konsumen. Data sekunder yang digunakan adalah studi literatur seperti jurnal, tesis, disertasi, data ekonomi dan buku teks. Teknik pengolahan data dilakukan melalui analisis BMC, SWOT, IFE dan EFE, grand strategy, dan $360^{\circ}$ Business Model Innovation. Hasil analisis memetakan perusahaan pada kuadran 1 yaitu posisi perusahaan berada pada pertumbuhan pasar yang tinggi dan posisi kompetitif yang kuat, sehingga perusahaan perlu perbaikan model bisnis melalui analisis $360^{\circ}$ BMI. Model tersebut digunakan untuk membantu melihat proses aktivitas bisnis mulai dari penciptaan nilai di hulu sampai mampu menjadi kompetensi inti di hilir dari sebuah proses bisnis.
\end{abstract}

Kata kunci: $360^{\circ}$ business model innovation, kanvas model bisnis, SWOT, usaha kecil menengah (UKM), value

\footnotetext{
${ }^{1}$ Corresponding author:

Email: rosyadelia@gmail.com
} 


\section{INTRODUCTION}

Economic growth can facilitate the process of economic development (Yasa and Arka, 2015). Micro, Small, and Medium Enterprises (MSMEs) are business units that have an important role in the national economy. According to the Ministry of Cooperatives, MSMEs contribution towards GDP is $60.34 \%$ in $2018,60 \%$ in $2019,61.07 \%$ in 2020 , and projected to increase by $1.29 \%$ in 2021 , and the projected contribution will reach 65\% in 2024 (Ministry of Cooperatives, 2020). The increasing MSMEs' contribution in each year shows potential and advantage from MSME business on producing consumer goods and services that are close to the people's needs. MSMEs have a characteristic as a flexible business (giving profit during a crisis) and elastic (easy to change business product, innovating, and improvising by adjusting the business condition according to the situation and opportunity).

At the beginning of 2020, Indonesians received the news about a virus called the corona. Coronavirus (COVID19) is a contagious disease caused by a newly discovered virus called corona (WHO, 2020). The effort made by the government to cut the virus chain is by applying Large-Scale Social Restrictions (PSBB) and carrying out social distancing. In the context of Pandemic, a new normal era is interpreted as the change of social behaviour by applying health protocols and restricting physical contact, and also changes in social activities (Griffith, 2020). The COVID-19 pandemic condition made an impact on the Indonesian economy, including MSMEs. BPS data shows a decreasing income of about $84 \%$ on Big to Medium-sized Businesses (UMB) and $82 \%$ on Micro to Small-sized Businesses (UMK). One solution to overcome this problem is to develop. MSMEs have a role in generating the country's economy; this is one of the research objectives to assist business actors in creating business innovations. (Fiseha and Oyelana, 2015).

Along with the development of current development and changes caused by the COVID-19 Pandemic, the consumer needs for consumables change from fresh produce to frozen foods; this also pushes the change in consumer behaviour, as $49 \%$ of society prefer to cook at home for consumption needs. This is in line with the dynamic consumer behaviour to adapt to their environment (Schiffman and Kanuk, 2010). Of so many products offered, the research result shows that one of the product categories which become a trend and is favoured by the public during the COVID-19 Pandemic is frozen food. Frozen food is packaged and frozen processed half-cooked food that has a longer shelf life than fresh food and is easier to serve.

CV XYZ is a small-sized business (UMK) established in 2012 in Bogor City, and its focus is to be a frozen food supplier. This business provides various ready-tocook products in the form of frozen foods, from meats, vegetables, fishes to various kinds of local fruits. $\mathrm{CV}$ $\mathrm{XYZ}$ started its sub-system production from the upper stream until the downstream. The raw materials used by the company are originated from fostered local farmers. These fostered farmers are located in Bogor and Bandung Regency. The selection of land location is adapted to the physical condition of the land and the climate factor, which is appropriate to the commodity to be cultivated. The main purpose of the company is to give sustainable satisfaction to the customers and to develop related stakeholders, as the company is not only doing business to gain benefits from the customers but also to open job vacancies.

The demand for CV XYZ products in 2020 increased up to more than $70 \%$. This, of course, has become an opportunity as well as a threat for the company since consumer behaviour tends to change according to their environment. The challenge faced by CV XYZ to compete in the frozen food market is quite big, like many other similar businesses. The high level of people's hygiene and the increasing demand for food becomes the challenge today. Besides, the company is now facing several obstacles on product development, channel limitation, and internal organization problems. COVID-19 Pandemic has made the society have the right for foods to fulfil their needs by prioritizing local foods. Several ways can be done to adapt to the new normal era, one of which is by innovation through business models.

A few relevant researches with the topic researched, one of which is the research of Saputra (2016) entitled Implementation of Design Thinking in Building a Business Model Innovation in a Printing Company. The business model innovation used is BMC. This model innovation is based on design thinking stages that can build business model innovation by giving extra value to each element. Permadi et al. (2016), in the Analysis of Business Model Development Canvas CV Kandura Keramik Bandung, analyzed the company's vision, mission and goals. Based on 
the analysis, some improvement programs including segmentation grouping, forming corporate partnership partners with the contemporary ceramics community, collaborating with suppliers, couriers, investors and experts who are competent, forming sub-divisions of quality control and colouring techniques, as well as recruiting potential human resources by providing special training for company employees. Efendi (2017), in the Rizky Food Business Model Development Analysis, development strategies can be carried out by adding partners, increasing business capital, increasing brand awareness, and improving the quality of human resources. Swastiati (2018) in Designing a CV Madu Apiari Mutiara Business Model with a Business Model Canvas Approach. Problems faced by the company in the form of aspects of legality, low product quality, and lack of response from the external side. The company prioritises the value proposition element so that the company can always capture customer needs and create innovation. Nita et al. (2020), in the Coffee Fresh Business Development Strategy with the Bussines Model Canvas and QSPM Methods, shows that the strategy that must be developed is growth and build strategy. The research Susanto (2021) about Business Sustainability Oriented Strategic Planning Using Triple Layer Business Model Canvas, the difference between the research done at $\mathrm{CV} X Y Z$ lies on their business strategy which focuses on the product innovation and services and optimizes the partnership of business overall.

Developing a business needs comprehensive planning. According to Demil and Lecocq (2010), a business model is a way to do innovation to execute a strategy to increase sales (Ratih and Mokhamad, 2019). Meanwhile, according to Slavik and Zagorsek (2016), it is stated that the business model can describe the company's resources which are arranged in a process to generate value. The relation between a business model with innovation and strategy produces a business model innovation (Teece, 2010). According to Gambardella and McGahan (2012), business model innovation describes the company's rationale by providing a value proposition for customers. BMC is a business model which shows the rationale of how an organization creates, gives, and captures values (Osterwalder and Pigneur, 2010) (Maghfirah, 2012). According to (Ching et al. 2013), the business model canvas should be used at the start of the business. After that, entrepreneurs can try new variations suitable for their respective businesses. The use of business model innovation aims to identify and analyze factors that can influence business sustainability Zhang et al. (2016). According to Amit and Zott (2012), having an innovative business model can create new markets or enable companies to create and take advantage of new opportunities in existing markets. For this reason, a business model must show significant opportunities both during periods of rapid economic growth and during times of occurs. Business model innovations can be constructed from existing business models (Markides, 2006). The business model focuses on value creation but remains focused on market segmentation, structured value chain revenue generation mechanisms, and competitive strategies (Chesbrough, 2007).

BMC approach is considered suitable to be applied in the food processing sector because ideas and creativity combined with reality are needed to develop a business. Framework on business model innovation becomes a device to improve business model canvas. Innovation has a role from simple development to creating a strategic value that can quickly respond to the environment if there are changes. A developed business model is expected to capture internal and external factors, from which then an alternative strategy can be arranged for business development (David, 2011). Hashim (2016) states that business strategies in various organizations are developed through different strategic approaches. The goal of this research is (1) to identify the relevant potencies and problems, (2) to design a business model for the development of CV XYZ, (3) to identify internal and external factors which influence the company business models, and (4) to create business model innovation of $\mathrm{CV}$ XYZ with $360^{\circ}$ business model innovation. The scope of the research is focused on UMK Frozen Food in Bogor City, limited to the business model development and its development strategy, but has not yet taken into consideration the financial feasibility.

\section{METHODS}

The research was carried out at CV XYZ, which is located in Bogor City. The research activity was conducted for four months, from February 2021 to May 2021. Location selection was carried out purposively with the consideration that $\mathrm{CV} \mathrm{XYZ} \mathrm{is} \mathrm{one} \mathrm{of} \mathrm{the}$ business units which provides frozen foods with special processing technique that has a continuous domestic demand and potential to develop. 
The type of data that are used in this research consist of primary and secondary data. Primary data were gained through observation, interviews with the experts such as the Cooperative Service and MSME of Bogor City, Agriculture Service of Bogor City. Secondary data were obtained through accessing information/data from a related institute such as BPS, Ministry of Cooperative, Ministry of Small and Medium Enterprises, and other relevant sources of data with the research topic such as scientific journals, books, government publications, and so on. The determination of the sample in this study was carried out using a non-probability sampling technique, namely by saturated sampling and totalling 30 people consisting of 25 internal CV XYZ who can give relevant information with the data needed and who are competent in their field and five consumers. The data collecting method started with direct observation and systemic recording. The interview was done by direct question and answer between the researcher and the interviewers. The interviewers in this research were chosen by considering them as competent stakeholders in their field. FGD was carried out through group discussion to gain generated data interaction and improve the depth of information on each aspect of the phenomenon.

The description of the framework of thought in this study can be seen in Figure 1. The method used in this research is a business model because the business model is a tool for describing the rationale for how organizations create, deliver and capture value. The tool used is a business model canvas, SWOT analysis, and $360^{\circ}$ business model innovation analysis. The processing and analysis stage carried out cover a descriptive analysis to collect the company's overall data and information on aspects related to the research object; business model mapping and identification by identifying nine elements of BMC; SWOT analysis to analyze internal and external factors of the company, and also to give an alternative strategy based on the combined factors. Values are then taken from the result of the analysis rated through weighting IFE and EFE matrics; grand strategy matrics are used to analyze the position of the company from the four-quadrant strategy. Another approach used to evaluate business model improvement comprehensively is the fiveelement $360^{\circ}$ business model innovation analysis, each of which frameworks are connected into one circle. From the analysis, the new business model canvas was mapped to become an input for CV XYZ business continuity in the new normal era.

This research hypothesizes that the company has a sustainable business model. This is based on the understanding from various perspectives that MSMEs have broad business opportunities, especially in the food processing industry. The research framework is shown in Figure 1. On one canvas sheet containing nine elements, you can see the business model being run and analyze how one element relates to other elements. The strategy formulation process begins with analyzing the internal and external environmental conditions to determine the company's condition. The analysis results are in the form of alternative strategies that are then developed to create innovations.

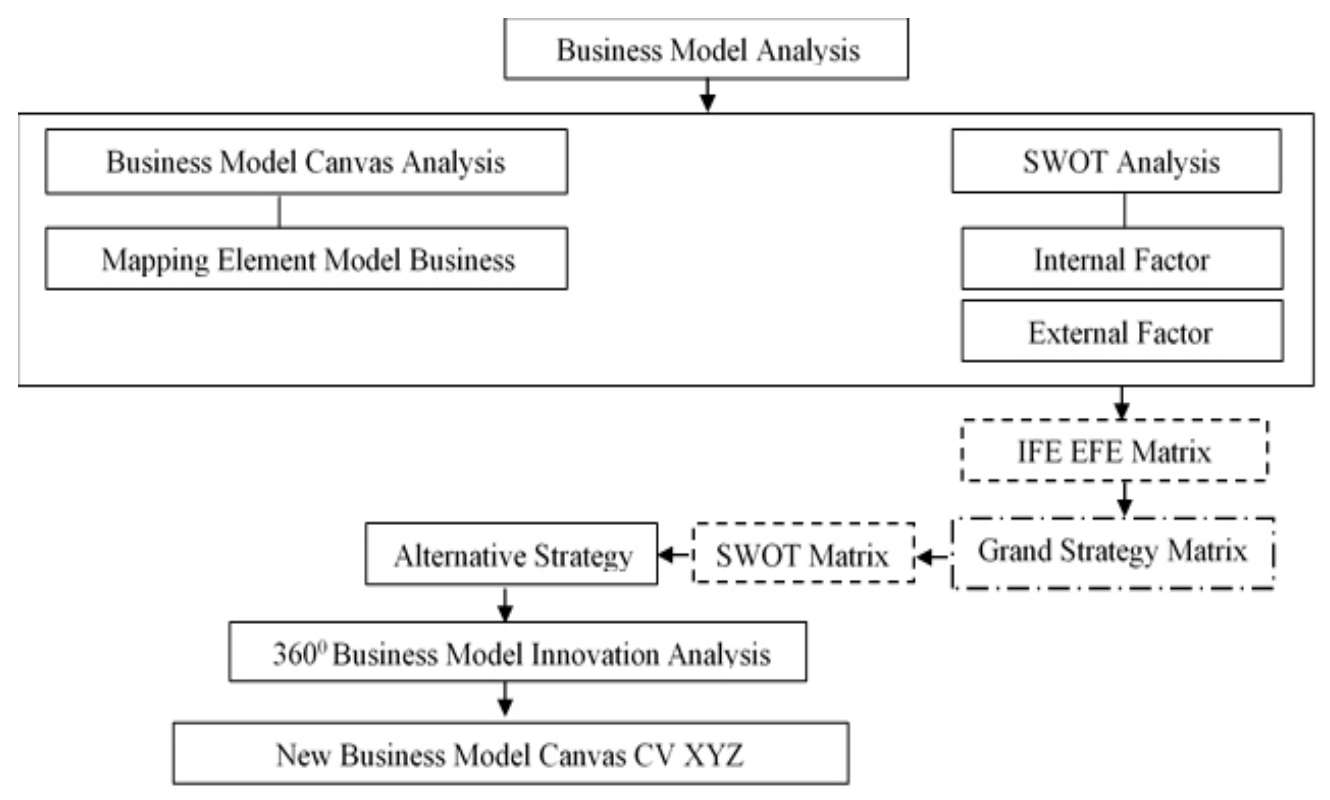

Figure 1. Research framework 


\section{RESULTS}

\section{XYZ Vision and Mission Analysis}

$\mathrm{CV} \mathrm{XYZ}$ is one of the small-scale business units in Bogor City that focuses on providing frozen food ingredients. This business provides various readyto-cook products in frozen form, ranging from meat, vegetables, fish to different frozen local fruits. Frozen products are processed through a freezing process and stored at low temperatures. The raw materials used by the company come from local farmers.

A company runs its business organization based on its vision and mission. The vision of the company is appealing and can provide a description of who the company is and what the company can give (desirable); the vision has also included the long-term purpose and objectives for the stakeholders, and it is realistic (feasible). Furthermore, the company's vision has a clear meaning (focused), and it can be measured to make it possible to measure the performance, whether the vision has reached its goal or not (measurable). The mission owned by the company can help the company improve its businesses, such as giving a direction and focusing on the steps taken. The mission of the company can be communicated to the stakeholders in or outside the organization on where the company is heading. The statement of the company mission is inspirational, as can be seen from the statement: carrying out innovation according to the market development.

\section{XYZ Business Model Identification}

The business model identification process is carried out through in-depth interviews involving internal parties of CV XYZ consisting of owners, directors, operational divisions, production divisions, finance divisions, and marketing divisions. The interview process aims to find out the opinion of the source based on the perspective in looking at a problem. Interviews conducted by researchers on the identification of business models were conducted without using particular guidelines. The resource persons are considered to have the capacity to provide relevant information to identify the nine elements of the business model canvas as a portrait of CV XYZ's current business model.

\section{Customer segments}

CV XYZ is a frozen food company that is safe without preservatives, so the segments of the company step into mass-market type, as the product can be consumed by children as well as adults with an age range from 12 to 50 years old. The target customer segment has no difference, no segmentation, and all will be served through the same distribution channel. The company customer segment is not limited by group, status, gender, and age, because anyone can consume the products sold by CV XYZ.

\section{Value propositions}

CV XYZ's value proposition is the most recent. This novelty can answer the needs and problems of customers, especially housewives and office workers. Previously, frozen foods were only made from meat. Still, at CV $\mathrm{XYZ}$ the company makes variations of frozen foods from vegetables and fruit to choose to buy food products from side dishes, vegetables to fruits. The values given by the company are based on the customer needs that are captured by the company as a business opportunity. Consumer products offered are frozen, with longer shelf life than vegetables, meats, and fresh fruit, and they do not require much time to process.

\section{Channels}

The purchase of CV XYZ products can be made through online and offline stores. The company combined two marketing channels to market their product through social media such as Instagram, Facebook, Website, Tokopedia, Shopee, Whatsapp, and offline stores located in Bogor City. Social media channels allow the company to directly communicate with the customers so that trust between the company and customers can be created.

\section{Customer relationships}

Customer relation created by the company towards the customers that are not the company's partners is a personal assistance type. This relationship is built starting from the purchasing process until the post-sale. On certain customers such as Sayurbox, the type of relationship built is dedicated personal assistance. Customer with this type of relationship is done by the company for long-term services to create partnership continuity. The relationship which involves the company and Sayurbox is specific and bound, following the agreement set by both parties. 


\section{Revenue streams}

The income flow of CV XYZ is included in the transaction revenue type since the income of the company is gained through a one-time payment. The income of CV XYZ is not only from product sales generated as the main source but also from other products. For example, the income received by the company is from selling frozen foods, snacks, drinks, and fresh vegetables such as green vegetables.

\section{Key resources}

The main resources needed to create services and products at $\mathrm{CV} \mathrm{XYZ}$ are divided into tangible and intangible. Physical resources owned by the company are in the form of buildings or a store, cars, equipment, and machines; human resources such as employees that are involved in the business process; and capital that are used for the overall business. All available resources are utilized optimally by the company to create high effectiveness value.

\section{Key activities}

The main activities carried out by CV XYZ started from the upstream sub-system, which is commodity cultivation by the garden farmers. The cultivation stage is started from land preparation, planting, and care. Seeds that are used are local. After the cultivation is finished, next is harvest and post-harvest to be sorted according to the demand. Post-harvest handling aims to maintain the quality of the product, especially vegetables so that they are not easily damaged and extend the shelf life until it can improve the economic value of vegetables. The frozen food production process is started by washing, cutting, and storing on a blast freezer with a maximum temperature below $-30^{\circ} \mathrm{C}$. Then, the company's marketing activities include product introduction by explaining the superiority of the product and the differentiation of the product so that it is better known by the customers.

\section{Key partnerships}

Farmers are one of the primary key partners for the company. Partners owned by the company to assist business activities are garden farmers, agents for frozen food packages and labels, the Ministry of Industry (Kemenperin), and several retailers in the city of Bogor such as Bozz Foods, Amin Fresh and Frozen, Kansa
Meat Shop, Bogor Segar, Jus Harmoni and Salad Bars. Cooperation with various parties can increase product innovation and positive services that can improve the performance of CV XYZ.

\section{Cost structures}

The company payment structure consists of variable and fixed costs. Variable costs include packaging raw foods purchase; label raw materials; vegetable seeds; catfish seeds; transportation fees; and electricity costs. Fixed costs consist of shop rent, employee salary, production machine depreciation, insurance, expedition, office stationaries, household items, and overtime pay.

\section{XYZ Business Model Canvas SWOT Analysis}

After identifying and mapping the nine business model canvas key elements, next is carrying out the SWOT analysis on each element available. The SWOT analysis on this research consists of internal factors such as $\mathrm{CV}$ $\mathrm{XYZ}$, including organization management and available resources; the next is analyzing external factors, which consist of suppliers, customers, and company partners.

\section{Customer segments}

The Head of the Department of Industry, Trade, and Cooperatives for SMEs in Bogor City said that its mass-market strength includes the prospect of high business growth because it consists of the majority of the population. This type of market is not homogeneous and has potential customers. The weakness of this segment is the lack of satisfaction with specific customer needs. The opportunity obtained is the one coming from another customer segment according to its business types, age, and territory. This customer segment is very potential for the company source of income. However, various customer needs become a threat to the company because the company cannot give proper value to the needs of certain customers.

\section{Value propositions}

Products have added value that can help increase the company's income; besides, added value can increase competitiveness. The weakness is the company has not yet had a substitute product. The availability of various product types offered becomes an opportunity because the company can concentrate on one-stop shopping. The busy society activities also become an opportunity 
for the company. The presence of product plagiarism and a high level of hygiene in society become a threat to the company.

\section{Channels}

The strength of the company can reach market segments widely through online and offline sales. The company's weakness is having not fully utilized the use of online marketing, including promotions and giving information, especially through the website. The opportunity in the new normal era is the use of digital marketing as a marketing strategy that can survive amid technological development. However, there are risks such as ineffectiveness of marketing content because it can cause errors relating to target and market segment, the vagueness of information, and the lack of trust in society. Another threat that might happen on using online marketing is when fraud occurs because the possibility of fraud practice is done by the seller or even the buyer, which can cause a loss.

\section{Customer relationships}

The company handles the needs of the customer, starting from purchasing until after-sales. The absence of a service system for excellent service has become the weakness. For the company, it can be an opportunity for the company to improve the follow-up towards the customer by giving a more comprehensive service standard that is supported by the good system, budget, and human resources so that customers can repeat their orders scale up the selling. The threat faced is the ability of the competitor to manage their relationship with their customers since keeping a good relationship with customers is important.

\section{Revenue streams}

The company has many sources of income other than selling frozen foods. However, the income received is from a low margin, so this becomes their weakness. On the other hand, the opportunity gained from a large number of reseller enthusiasts can increase profit and press the operational budget. The threat to the company is the due payment system.

\section{Key resources}

Having production land can be a strength for the company because the company can utilize the land by producing various types of commodities that can be used as agroindustry. The weakness is the production machine capacity is limited, and the organization management system is not optimal. Rapid machine technological development becomes an opportunity for the company because it can help the production activity to be more effective and efficient; however, the resistance of human resources is a threat that can hinder the business.

\section{Key activities}

The strength of the key activity elementsis theoperational activity starting from raw materials procurement until delivery to the customer that is done according to the SOP. The COVID-19 pandemic era demands the company to pay more attention to sanitation and hygiene. The weakness is the long-distance farmland location access that needs higher costs that can damage the farmer's productivity. Cooperation with various parties can be an opportunity for the company to support product development, especially in creating innovation. Newmarket innovation in the middle of the new normal era becomes an opportunity to fulfil the customers' needs; however, the marketing activity, especially direct social activities, becomes a threat to the company.

\section{Key partnerships}

The strength of the company is the kinship relationship with key partners, but still keeping it professional. The weakness is that the low autonomy principle in business ethics. This principle is based on their ability and attitude when making a decision. The company still depends on other parties to make a decision. The opportunity from this element is that the company has a wide business opportunity. This opportunity comes from the problems that occur and the unfulfilled needs. The threat they are facing is the ability of the competitor that can penetrate the strategic partners.

\section{Cost structures}

The strength possessed is shown by the ability of the company to predict the cost incurred. The company's weakness is that the recording, which includes sales, purchases, incomes, and outcomes, is still done manually. The company's opportunity is that cooperation with the government enables promotion fees to be reduced through digital platforms. On the 
other hand, rejected products become a threat for the company because the company must spend on product returns. Other than that, high raw materials fluctuation fees and promotion fees also become a threat because this can also be related to the additional expenses.

\section{Company Strategy Analysis and Company Strategy}

Alternative strategies are arranged according to the internal factors (strengths and weaknesses) as well as external factors (opportunities and threats). From the results of the factor analysis according to the nine elements of the business model canvas, the next stage is studying those factors to see which factors are the most influential following the results of the interview with respondents and observation on the company by using IFE and EFE matrices. The number of respondents is more than one so that the results of IFE and EFE matrices are semi-aspirational, and thus the position of the company can be described on the grand strategy matrices. The total score of IFE matrices is 1.89 (X-axis), and the total score of EFE matrices is 1.71 (Y-axis). The combination of the result of IFE and EFE matrices produces the grand strategy matrices. The grand strategy matrices result indicates that the company's position is on the higher market growth and the strong competitive position. The selection of an alternative strategy which is corresponding to the environment of the company is, among others, the market development strategy, market penetration, product development, forward integration, backward integration, horizontal integration, and concentric diversification.

\section{XYZ $360^{\circ}$ Business Model Innovation Analysis}

Complexity in a business becomes an opportunity and also a challenge for the company to formulate business models that dynamically can be adjusted to the internal and external changes of the company. Business models which have been described above must be re-engineered to optimize the complex resources for business continuity. Furthermore, business models must be adapted to the changes happening, especially in the new normal era. This era requires a business to be more innovative and able to answer the problems faced by the customers, besides adjusting to the environment. The $360^{\circ}$ business model innovation analysis has five elements, each of which is connected into one circle. These are the explanation of CV XYZ's business model using $360^{\circ}$ Business Model Innovation.

\section{Value creation}

The creation of value on CV XYZ business models comes from core competency, key resources, and value network. The stages that can be done on creating values for CV XYZ are understanding and fulfilling the needs of the customer and understanding what is considered valuable for the customer. Creating company values lies in unique vegetables, meats, and frozen fruits. Products are created for all customers. Even though it sounds simple, the products that are supported by the quality of raw materials and resources performance become a distinct advantage.

\section{Value proposition}

CV XYZ provides convenience to fulfil daily consumption needs. The offered products give value through different mixtures of elements. This value is quantitative. The product can still be received by the customer and has a high service, meaning it does not need a long time for the customers to receive the products because the product is frozen. The qualitative values are interesting packaging design that contains simple concepts, using real pictures of the product, adding information data on servings and storage, labelling BPOM and halal, and using packaging that can maintain the quality of the product. The production process is assisted by technology and through special techniques to produce good product quality. The other value that the company can give is that the company can provide information on the upstream sub-system activities using standard health protocol service to make sure that the products sold are safe.

\section{Value delivery}

The success of value creation needs the success of value delivery. Company value delivery during COVID19 Pandemic also gives an advantage to CV XYZ because online distribution becomes an opportunity to resolve the needs of customers, which so far have been unreachable. A delivery service that can be applied in the new normal era is cooperating with Gojek and using delivery service through an expedition to reduce physical contacts and avoid crowds; however, the company must make sure that the used packaging is safe. The company needs to maintain the hygiene of the product by applying special operational standards. 


\section{Value capture}

The value created can be captured well by the customers and even the company. For the company, value acquisition is taken from the sales results on the main products, snacks, drinks, and herbs. For the customers, value acquisition is taken from customer satisfaction towards the value proposition. The experience of the customers when consuming the product can also become a value capture.

\section{Value communication}

The communication value of the company can be seen through sales promotion, one of which is on specific moments where bundling product promo is held. Through exhibition or Trade Expo Indonesia, the company can give information on what the company offers and what value is different from another competitor. On the website, the company communicates the value of the company information, such as the company's image, to build trust with the potential customers. The company can also go the extra mile to win the customers' hearts if the competitor chooses to see and read the opportunity. The company can show its existence so that business becomes more flexible and innovative.

\section{The revised CV XYZ business model}

Organizational development for the continuity of the company can be done through several changes. The company can make changes after finding out the factors that can push the organization to make changes. Business model canvas changes at $\mathrm{CV} X Y Z$ are done through SWOT analysis in each business model element and $360^{\circ}$ business model innovation analysis. Through these analyses, the company's prospects must be maintained and developed and find out what obstacles are encountered and what solution is needed to fix them. Repair conducted on business model functions to optimize the performance of the overall business models

\section{Revised of customer segments}

The company customer segment is a mass market with ages ranging from children, teenagers and adults. This customer segment has strengths and weaknesses; however, the company needs to group the customer segments by seeing the changes made, especially on dynamic consumer behaviour. This is required to focus on making proper value propositions with each customer segment group and provide proper key resources.

\section{Revised of Value Proposition}

The company value proposition is very useful for the needs of the society to fulfil the food needs and advance regional commodities in terms of novelty innovations, production process, and value chain. The innovation, in this case, refers to the changes made adapted to the environment and market demands. This innovation needs to be done by the company since the new normal era is challenging for the company. Innovation is also aimed to sustain the business, minimize competition and accommodate the customer needs. For example, the customers can enjoy dry fruits and vegetables as a snack or can be added to the mixture of the trail. Boosters towards the value propositions can also be done by the company by giving discounts to certain products, a guarantee of a cashback, and a free product bonus with minimum purchase.

\section{Revised of channels}

To optimize the channels, the company needs to optimize its social media, websites, SEOs on search engines such as Google, Facebook, Shopee, Tokopedia, Whatsapp, and also Youtube channel, multiplying its marketing associates and conducting training routinely, and also optimizing its salespersons to educate targets to gain knowledge of CV XYZ products.

\section{Revised of key activities}

The company can do repairs on marketing activities by holding a campaign to attract targets, one of which the company can apply cross-selling by giving extra product offers when the customer is doing a transaction. Other types of approaches that can be done are hard selling and soft selling. Soft selling works for building a brand image of CV XYZ and has a longterm relationship because there is a linkage between the value of the product with the needs and desires, such as holding a giveaway through Instagram. The company can also apply hard selling because customers tend to learn about the offered product quicker, and it pushes them to buy, and it is also effective to reach the target in a short time. Hard selling can be done by giving discounts on the product, giving a promo of buying one get one event, holding a door prize event, and making a bundling package. 


\section{Revised of key resources}

Repair this element by adding company storage assets equipped with cool storage to guarantee the crop's quality, especially vegetable commodity, so that it is not easily ruined.

\section{Revised of key partnerships}

The development that can be done by the company is establishing cooperation with modern market retailers (minimarket, supermarket, and hypermarket). The upper-middle-class tends to buy products in the supermarket by considering certain criteria. This can be an option for the company to cooperate with supermarkets. In addition, the company can choose supermarkets that apply low fees.

\section{Revised of customer relationships}

The repair that can be done is adding administrative workers in different customer services in each type of customer segment. This is to help the company to understand the customers more. The customer relationship element also needs to be improved through personal services by utilizing owned social media. This needs to be done to improve and maintain the communication intensity between customers or future customers with CV XYZ. Giving information such as location, products, and other information needed by the customer can be done through Instagram and the website. Maintaining customers online is a good choice because the company has the strength and ability to monitor consumer behaviour without violating the customer's privacy.

\section{Managerial Implication}

CV XYZ needs to socialize the company's plan to the company internals concerning what needs to be prepared, such as budget and technical preparation. CV $\mathrm{XYZ}$ needs to improve its employee performance by giving the right training as an evaluation step for the results of business model repair; weekly, monthly and quarterly evaluation is needed to evaluate the progress and see the impact that can happen from the result new business model.

\section{CONCLUSIONS AND RECOMMENDATIONS}

\section{Conclusions}

Based on the nine elements of the business model canvas, it can be seen that the business model of CV $\mathrm{XYZ}$ has elements that need to be fixed, for example, on the customer segments, the company needs to add a customer segment for those with special needs (niche market) so that the company can fulfil the needs of this specific customers. On the repair of value proposition, the company needs to create substitute products such as dry fruits and vegetables. On the repair of channel element, the company needs to optimize their online sales channel and use SEO on Google search engine so that customers can easily know the overall information of CV XYZ. On the repair of key activities element, the company needs the fix its marketing activity by holding a campaign with specific themes and building a stronger branding. On the repair of key partnership elements, the company can have cooperated with modern markets to reach a broad market. On the repair of customer relationship element, the company needs to improve its services to maintain its communication intensity with the customers.

The analysis results show that CV XYZ needs some changes that are adaptable to the new normal era condition. From the result of the SWOT analysis and the grand strategy matrices, it can be seen that the company's position is on the first quadrant with a strong competitive position and market growth. The step that can be taken according to the $360^{\circ}$ business model innovation of the five frameworks is the company needs to expand the market segment to improve the sale volumes by increasing the product added value without decreasing their product characteristics, namely fresh, improving the quality of the product and its services also strive for overall business consistency.

\section{Recommendations}

This research emphasizes the development of the company's business model according to the business model canvas perspectives. However, the analysis results show that some aspects can be studied further, such as research on strategic planning to know the stages of the more measurable business model development by using a strategic priority. Another suggestion that can be given is the involvement of external parties as experts and quantitative data to avoid bias. 


\section{REFERENCES}

Amit R, Zott C. 2012. Creating value through business model innovation. Journal MIT Sloan Management Review 53(3):41-49.

Chesbrough H. 2007. Business model innovation: It's not just about technology anymore. Journal Strategy \& Leadership 35(6):12-17.https://doi. org/10.1108/10878570710833714

Ching W, Hong Y, Clemens F. 2013. Criticisms, variations, and experiences with business model canvas. Journal of European for Research Training and Development 4(1):132-144.

David FR. 2011. Strategic Management Concept \& Cases. 13th ed. New Jersey: Prentice-Hall.

Demil B, Lecocq X. 2010. Business model evolution: In search of dynamic consistency. Long Range Planning 43(2-3):227-246.https://doi. org/10.1016/j.lrp.2010.02.004

Efendi I. 2017. Analisis pengembangan model bisnis Rizky Food [tesis]. Bogor: Sekolah Program Pascasarjana, Institut Pertanian Bogor.

Fiseha GG, Oyelana AA. 2015. An assesmenet of the roles of small and medium enterprises (SMEs) in the local economic development in South Africa. Journal of Economics 6(3):280-290.https://doi. org/10.1080/09765239.2015.11917617

Gambardella A, McGahan AM. 2010. Business model innovation: General purpose technologies and their implications for industry structure. Long Range Plan 43:262-271.https://doi. org/10.1016/j.lrp.2009.07.009

Griffith K. 2020. The new normal after coronavirus. https://www.ksn.com/news/capitol-bureau/thenew-normal-after-coronavirus/. [9 Jan 2021].

Hashim MK. 2016. Approaches to formulating business strategy. Arabian Journal of Business and Management 7(1):1-7.

Maghfirah. 2012.E-Business analysis of garut university using the business model canvas. International Journal of Science and Research 2(1):1-5.

Markides C, Charitou CD. 2004. Competing with dual business models: A contingency approach. Academy of Management 18(3):22-36.https:// doi.org/10.5465/ame.2004.14776164
Nita K, Rizki A, Melinda LP. 2020. Strategi pengembangan bisnis Coffee Fresh dengan Metode Business Model Canvas dan QSPM. Agroindustrial Technology Journal 4(2). http:// dx.doi.org/10.21111/atj.v4i2.5077.

Osterwalder A, Pigneur Y. 2010. Business model generation: A handbook for visionaries, game changers, and challengers. Yves:288.

Permadi B. 2015. Analisis pengembangan model bisnis CV Kandura Keramik [tesis]. Bogor: Sekolah Program Pascasarjana, Institut Pertanian Bogor.

Ratih F, Mokhamad AS. 2019. Model bisnis kanvas sebagai solusi inovasi bagi yang kecil bisnis. Jurnal Ilmu Manajemen dan Bisnis 10(2):197203.

Saputra TA. 2016. Implementasi design thinking dalam membangun inovasi model bisnis perusahaan percetakan. Jurnal Agora 4(1):833-842.

Schiffman LG, Kanuk LL. 2010. Consumer Behavior. Ed. ke-10. New Jersey: Pearson Education.

Slavik S, Zagorsek B. 2016. Relationship between business strategy and business model studied in a sample of service companies. Journal of Competitiveness 8(4):72-84. doi:http://dx.doi. org/10.7441/joc.2016.04.05.

Swastiati DD. 2018. Perancangan model bisnis cv madu apiari mutiara dengan pendekatan business model canvas [tesis]. Bogor: Program Sekolah Pascasarjana, Institut Pertanian Bogor.

Susanto MS. 2021. Business sustainability oriented strategic planning using triple layer business model canvas (Case Study: Ghi Training). Jurnal Aplikasi Manajemen dan Bisnis 7(2):1-12.

Teece DJ. 2010. Business models, business strategy and innovation. Long Range Planning 43(2):172194. https://doi.org/10.1016/j.lrp.2009.07.003

[WHO] World Health Organization. 2020. Coronavirus. https://www.who.int/health-topics/ coronavirus\#tab=tab_1. [9 Jan 2021].

Yasa IKA, Arka S. 2015. Pengaruh pertumbuhan ekonomi dan disparitas pendapatan antardaerah terhadap kesejahteraan masyarakat Provinsi Bali. Jurnal Ekonomi Kuantitaif Terapan 8(1):63-71.

Zhang Y, Zhao S, Xu X. 2016. Business model innovation: an integrated approach based on elements and functions. Information Technology and Management 17(3):303-310. 